\title{
KAJIAN TERHADAP PENCEMARAN NAMA BAIK MELALUI FACEBOOK
}

Oleh : IWAN SETIAWAN ${ }^{*}$

(iwan78fhunigal@gmail.com)

\begin{abstract}
The criminal offense of defamation or defamation through Facebook is a complaint that is regulated in Chapter XVI of the Criminal Code, namely Article 310 of the Criminal Code up to Article 321 of the Criminal Code Jo Law Number 19 Year 2016 concerning Amendment to Law Number 11 of 2008 concerning Information and Electronic Transactions, which requires victims of defamation to make complaints to the authorities. Content of explanatory norms Article 27 of Law Number 19 Year 2016 concerning Amendment to Law Number 11 Year 2008 concerning Electronic Information and Transactions, indirectly adopts consideration of Constitutional Court Decision Number 50 / PUU-VI / 2008 Jo Decision of Constitutional Court Number 2 / PUU-VII / 2009.
\end{abstract}

Keywords: Defamation, Facebook

\begin{abstract}
Abstrak
Tindak pidana penghinaan atau pencemaran nama baik melalui facebook merupakan delik aduan yang diatur dalam Bab XVI KUHP yakni Pasal 310 KUHP sampai dengan Pasal 321 KUHP Jo Undang-Undang Nomor 19 Tahun 2016 tentang Perubahan atas Undang-Undang Nomor 11 Tahun 2008 tentang Informasi Dan Transaksi Elektronik, yang mengharuskan korban atas pencemaran nama baik membuat pengaduan kepada pihak yang berwajib. Muatan norma penjelasan Pasal 27 Undang-Undang Nomor 19 Tahun 2016 tentang Perubahan atas Undang-Undang Nomor 11 Tahun 2008 tentang Informasi Dan Transaksi Elektronik, secara tidak langsung mengadopsi pertimbangan Putusan Mahkamah Konstitusi Nomor 50/PUUVI/2008 Jo Putusan MK Nomor 2/PUU-VII/2009.
\end{abstract}

Kata Kunci: Pencemaran nama baik, Facebook

\section{PENDAHULUAN}

Sebagai negara hukum, Indonesia menganut sistem kedaulatan hukum atau supremasi hukum, di mana hukum mempunyai kekuasaan tertinggi dalam suatu negara, dan ciri-ciri khas dari negara hukum dapat terlihat dalam praktek penyelenggaraan pemerintahan yaitu dengan adanya kekuasaan kehakiman yang

\footnotetext{
*) Dosen Tetap Fakultas Hukum Universitas Galuh
} 
bebas dan tidak memihak serta adanya pengakuan akan Hak Asasi Manusia. Walaupun dalam praktek penyelenggaraannya masih belum sempurna dan banyak terjadi penyelewengan terhadap ciri-ciri khas negara hukum tersebut. (Jimly Asshiddiqie, 2010: 2)

Sejak bergulirnya era Reformasi yang ditandai dengan runtuhnya rezim Orde Baru, terjadi perubahan dalam iklim demokrasi di negara Republik Indonesia. Kebebasan adalah menjadi salah satu pilar utamanya. Siapa saja berhak menyuarakan pendapat dan keinginannya tanpa tekanan dari pihak manapun, karena sudah dijamin oleh Undang-Undang Dasar Negara Republik Indonesia Tahun 1945. Angin reformasi mengantarkan masyarakat ke dalam era kebebasan yang sesungguhnya setelah sekian lama hidup dalam pemasungan, pengekangan dan pengungkungan. (Jimly Asshiddiqie, 2010: 3)

Kemerdekaan berbicara, berekspresi dan kemerdekaan pers adalah hak asasi manusia, dalam Negara demokrasi yang kini menjadi pilihan Indonesia. Hak tersebut harus di jamin. Ketetapan untuk itu telah di tempuh Negara lewat TAP MPR NO. XVII tentang Hak Asasi Manusia yang selanjutnya dikukuhkan oleh konstitusi Republik Indonesia melalui amandemen Undang-Undang Dasar Negara Republik Indonesia Tahun 1945. Amandemen terhadap UUD 1945 yang menyangkut jaminan terhadap kemerdekaan berpendapat, berekspresi, selanjutnya kemerdekaan pers tertuang dalam pasal $28 \mathrm{E}$ ayat (2) UUD 1945 yang menyatakan bahwa "Setiap orang berhak atas kebebasan meyakini kepercayaan, menyatakan pikiran dan sikap, sesuai dengan hati nuraninya.".

Teknologi informatika dan komunikasi telah berkembang demikian pesat. Cyber (komputer) telah melahirkan internet yang membawa fenomena baru di bidang media massa. Dewasa ini, revolusi media massa telah melahirkan media baru yang bisa disebut sebagai media sosial. Perkembangan teknologi saat ini mengantarkan masyarakat menuju globalisasi telekomunikasi media dan informatika. Kemajuan teknologi komunikasi ini sudah demikian menjamur di kalangan masyarakat, sehingga pengenalan alat elektronik telah menunjukkan intesitasnya sebagai media informasi dan telekomunikasi.

Melalui internet pula kegiatan komunitas komersial menjadi bagian terbesar dan pesat pertumbuhannya serta menembus berbagai batas Negara, bahkan melalui jaringan ini kegiatan pasar di dunia bisa diketahui selama 24 jam. Melalui dunia internet atau disebut juga cyber space, apapun dapat dilakukan. Segi positif dari 
dunia maya ini tentu saja menambah trend perkembangan teknologi dunia dengan segala bentuk kreatifitas manusia. Namun, dampak negatif pun tidak bisa dihindari. Tatkala pornografi marak di media internet, masyarakat pun tak bisa berbuat banyak. Seiring dengan perkembangan teknologi internet, menyebabkan munculnya kejahatan yang disebut dengan cyber crime atau kejahatan melalui jaringan internet.

Munculnya beberapa kasus cyber crime di Indonesia, seperti pencurian kartu kredit, pencemaran nama baik, hacking beberapa situs, menyadap transmisi data orang lain, misalnya email dan memanipulasi data dengan cara menyiapkan perintah yang tidak dikehendaki ke dalam program Komputer. Sehingga dalam kejahatan komputer dimungkinkan adanya delik formil dan delik materil. Delik formil adalah perbuatan seseorang yang memasuki Komputer orang lain tanpa izin, sedangkan delik materil adalah perbuatan yang menimbulkan akibat kerugian bagi orang lain. Adanya cyber crime telah menjadi ancaman stabilitas, sehingga pemerintah sulit mengimbangi teknik kejahatan yang dilakukan dengan teknoligi computer, khususnya jaringan internet (RiversI William dkk, 2003: 56).

Media sosial sangat berpengaruh besar terhadap perkembangan dan perubahan masyarakat Indonesia, perubahannya pun beragam bisa membawa perubahan yang lebih baik, bahkan perubahan yang sangat buruk pun bisa terjadi di media sosial. Media sosial adalah sebuah media online, di mana para pengguna dapat dengan mudah beradaptasi, berbagi, dan menciptakan isi. Media sosial meliputi blog, jejaring sosial, wiki, forum dan dunia virtual. Blog, jejaring sosial, dan wiki merupakan bentuk media sosial yang paling umum digunakan oleh masyarakat di seluruh dunia. Media sosial sangat beragam, sehingga masyarakat dapat mengaskes dengan mudah dan memanfaatkannya untuk interaksi sosial. Demikian mudah interaksi sosial dijalin melalui sosial media, maka komunikasi dua arah ini bias menjadi bersifat privat maupun terbuka, sering tidak disadari bahwa ada norma-norma yang mengikat interaksi tersebut.

Tak jarang seseorang memanfaatkan media sosial sebagai sarana dalam menyampaikan pendapat, informasi, ataupun berekspresi namun diperlukan kehatihatian dalam penggunaannya karena bisa saja pendapat maupun informasi yang disampaikan berbenturan dengan rasa kehormatan orang lain atau yang berdampak pada pencemaran nama baik terhadap orang lain.

Terdapat kasus di Kota Tasikmalaya terkait pencemaran nama baik melalui facebook yakni kasus yang menjerat Ketua DPP Gaza H. Aas Dani Hasbuna ke meja 
hijau bermula dari postingan terdakwa di media sosial facebook pada 11 Desember 2016. Terdakwa membagikan postingan berupa gambar lambang PDIP dengan tulisan dibawahnya "boikot partai kafir ini sekarang juga...! haram muslim memilih partai ini...". Pada kasus ini, H. Aas Dani Hasbuna dijerat Pasal 45 ayat 3 juncto Pasal 27 ayat 3 Undang-Undang Nomor 11 Tahun 2008 tentang Informasi Dan Transaksi Elektronik. Dengan pertimbangan terpidana mengalami sakit gagal ginjal dan diharuskan menjalani perawatan, majelis hakim pun memutuskan untuk menetapkan Aas menjadi tahanan kota. (https://www.jpnn.com/news/penghina-pdipdivonis-1-tahun-penjara).

\section{PEMBAHASAN}

Pencemaran nama baik merupakan salah satu bentuk khusus dari perbuatan melawan hukum. Istilah yang dipakai mengenai bentuk perbuatan melawan hukum ini ada yang mengatakan pencemaran nama baik, namun ada pula yang mengatakan sebagai penghinaan. Penghinaan atau dalam bahasa asing disebut defamation, secara harfiah diartikan sebagai sebuah pencemaran nama baik dan merupakan salah satu bentuk khusus dari perbuatan tindakan yang merugikan nama baik dan kehormatan seseorang.

Pencemaran nama baik/ penghinaan terdiri atas dua unsur, yakni tindakan pencemaran dan objek yang dicemarkan berupa nama baik seseorang. Pencemaran nama baik bisa diartikan sebagai perbuatan/ suatu tindakan seseorang yang mengakibatkan tercemarnya nama baik seorang lain atau objek yang dihina. Tindak pidana pencemaran nama baik dapat dikelompokan berdasarkan sarana yang digunakan antara lain :

a) Pencemaran nama baik secara konvensional

Pencemaran nama baik secara konvensional yaitu pencemaran nama baik yang dilakukan dengan cara-cara biasa seperti berbuat/ bertindak dengan lisan ataupun dengan tertulis. Pencemaran dengan menggunakan lisan yakni berucap dengan maksud untuk menyerang atau membuat malu nama baik/ kehormatan orang lain di depan khalayak ramai. Sedangkan pencemaran nama baik secara tertulis yakni dengan membuat tulisan ataupun gambar dengan maksud menyerang kehormatan / nama baik seseorang pada suatu media dan disebarkan dengan maksud untuk diketahui khalayak ramai. 
b) Pencemaran nama baik dengan memanfaatkan teknologi informasi.

Dimana pencemaran nama baik ini dilakukan dengan cara memanfaatkan teknologi informasi dengan cara lisan maupun dengan cara tertulis. Pencemaran nama baik dengan memanfaatkan teknologi informasi menggunakan lisan biasanya dilakukan dengan melalui telepon atau pesan suara yang mana dimaksud untuk menyerang nama baik seseorang. Pencemaran nama baik menggunakan teknologi informasi dilakukan secara tertulis dilakukan dengan cara membuat tulisan atau gambar berupa dokumen elektronik dengan maksud untuk menyerang kehormatan atau nama baik orang lain (Atven Vemanda Putra: 2013).

Pada dasarnya, tindak pidana penghinaan atau pencemaran nama baik merupakan delik aduan yang di atur dalam Bab XVI KUHP yakni Pasal 310 KUHP sampai dengan Pasal 321 KUHP. Salah satu norma yang berimplikasi pada ruang sengketa adalah norma hukum. Keberadaan Kitab Undang-Undang Hukum Pidana Pasal 310 ayat (1) juncto Undang-Undang Nomor 19 Tahun 2016 tentang Perubahan atas Undang-Undang Nomor 11 Tahun 2008 tentang Informasi Dan Transaksi Elektronik Informasi, pada dasarnya menjadi rambu-rambu dalam interaksi sosial melalui internet dan juga mengatur berbagai ancaman hukuman bagi kejahatan melalui internet. Sementara dalam KUHP, khususnya Pasal 310 Ayat(1) juga diatur masalah pencemaran nama baik. Pemberlakuan pasal penghinaan atau pencemaran nama baik yang diatur baik pada KUHP maupun pada peraturan perundangundangan lainnya sering disorot tajam tidak hanya oleh praktisi hukum tetapi juga oleh masyarakat. Aturan itu dinilai banyak menghambat kebebasan berekspresi dan menyampaikan pendapat di masyarakat.

Berdasarkan penjelasan dalam Pasal $310 \mathrm{KUHP}$, penghinaan memiliki pengertian yaitu "menyerang kehormatan dan nama baik seseorang". Yang diserang itu biasanya merasa malu. Kehormatan yang diserang disini hanya mengenai kehormatan yang dapat dicemarkan. Berdasarkan sudut pandang hukum, pencemaran nama baik berdasarkan penjelasan dalam pasal $310 \mathrm{KUHP}$, memiliki pengertian yaitu "menyerang kehormatan dan nama baik seseorang" yang diserang itu biasanya merasa malu. Sedangkan dari sudut pandang masyarakat pencemaran nama baik merupakan suatu perbuatan yang memfitnah seseorang yang belum pasti benar sehingga orang tersebut merasa malu dan merasa kehormatannya dicemarkan. 
Dalam teori penghinaan seringkali dikaitkan dengan kehormatan dari seseorang. Jika ditinjau dari segi istilah pengertian dari kehormatan dapat didasarkan atas beberapa teori, yaitu :

\section{a. Teori De subjectieve opvatting}

Teori ini menyatakan bahwa pengertian kehormatan dapat disamakan dengan "rasa kehormatan". Pendapat ini karena beberapa alasan tidak lagi diterapkan oleh ilmu hukum maupun yurisprudensi. Alasan-alasan tersebut adalah:

1) apabila Teori ini dijadikan ukuran untuk menentukan apakah kehormatan seseorang tersinggung atau tidak, maka akan sulit jika yang dihadapi ialah orang-orang yang "rasa kehormatannya" tebal (overgevoeling) atau yang kurang atau yang sama sekali tidak mempunyai rasa kehormatan.

2) dengan menganut pandangan subjektif, maka hak untuk memberikan pendapat secara bebas menjadi berkurang.

3) bahwa dengan menganut pandangan ini, sebetulnya kita melepaskan de jurisdiche begrifsbepalingen dan memasuki psychologich (Jumardi, 2014: 54).

\section{b. Teori De objectieve opvatting}

Teori ini menyatakan bahwa pengertian kehormatan dapat didasarkan kepada dua pandangan, yang antara lain :

1) pandangan yang membatasi diri pada pengakuan nilai-nilai moral dari manusia;

2) pandangan yang hendak memperluas, yaitu tidak membatasi diri pada pengakuan nilai-nilai moral dari manusia, tetapi memperluasnya dengan semua faktor yang dapat digunakan sebagai pegangan oleh manusia (Jumardi, 2014: 54).

Kehormatan merupakan rasa harga diri (eergevoel, perasaan terhormat) yang muncul dalam batin seseorang. Jadi, "harga dirr" merupakan sesuatu yang mengenai segi "intern" orang perorangan. Sedangkan "nama baik" merupakan penghargaan yang datang dari luar, dari masyarakat sekeliling, yang berkaitan dengan tindakan atau sikap seseorang, atau kedudukan seseorang dalam masyarakat. "Nama baik" bersifat extern. Para pakar belum sependapat tentang arti dan definisi kehormatan 
dan nama baik, tetapi sependapat bahwa kehormatan dan nama baik menjadi hak seseorang atau hak asasi setiap manusia. Selanjutnya, dari kata "atau" tersebut di atas, bisa disimpulkan bahwa syarat melanggar nama baik atau menyerang kehormatan bukan merupakan syarat kumulatif untuk adanya penghinaan, melainkan merupakan syarat alternatif. Dipenuhinya salah satu saja dari dua unsur itu (di samping unsur-unsur khusus lain) sudah cukup untuk adanya tindak pidana penghinaan.

Aturan hukum tentang pencemaran nama baik melalui facebook terdapat pada Pasal 27 ayat (3) Undang-Undang Republik Indonesia Nomor 19 Tahun 2016 tentang Perubahan atas Undang-Undang Republik Indonesia Nomor 11 Tahun 2008 tentang Informasi Dan Transaksi Elektronik Informasi yang berbunyi "Setiap orang dengan sengaja dan tanpa hak mendistribusikan dan/ atau mentransmisikan dan/ atau membuat dapat diaksesnya Informasi Elektronik dan/ atau Dokumen Elektronik yang memiliki muatan penghinaan dan/ atau pencemaran nama baik" dan Pasal 45 ayat (3) Undang-Undang Republik Indonesia Nomor 19 Tahun 2016 tentang Perubahan atas Undang-Undang Republik Indonesia Nomor 11 Tahun 2008 tentang Informasi Dan Transaksi Elektronik Informasi sebagai aturan khususnya (lex spesialis).

Setiap Orang yang dengan sengaja dan tanpa hak mendistribusikan dan/atau mentransmisikan dan/atau membuat dapat diaksesnya Informasi Elektronik dan/atau Dokumen Elektronik yang memiliki muatan penghinaan dan/atau pencemaran nama baik sebagaimana dimaksud dalam Pasal 27 ayat (3) dipidana dengan pidana penjara paling lama 4 (empat) tahun dan/atau denda paling banyak Rp750.000.000,00 (tujuh ratus lima puluh juta rupiah).

Delik pencemaran nama baik melalui facebook merupakan penyalagunaan teknologi informasi, suatu tindakan yang tidak memperhatikan nilai nilai agama dan sosial budaya masyarakat Indonesia.

Undang-Undang Republik Indonesia Nomor 19 Tahun 2016 tentang Perubahan atas Undang-Undang Republik Indonesia Nomor 11 Tahun 2008 tentang Informasi Dan Transaksi Elektronik Informasi, telah melakukan perubahan Pasal 45 dan penambahan Pasal $45 \mathrm{~A}$ dan $45 \mathrm{~B}$ yang kesemuanya berfungsi menjerat pelaku tindak pidana yang berkaitan dengan kejahatan Teknologi Informasi (Cyber Crime).

Perubahan elemen dasar ketentuan Pasal 45 ayat (1) Undang-Undang Republik Indonesia Nomor 11 Tahun 2008 tentang Informasi Dan Transaksi Elektronik menjadi Pasal 45 ayat (3) Undang-Undang Republik Indonesia Nomor 19 
Tahun 2016 tentang Perubahan atas Undang-Undang Republik Indonesia Nomor 11 Tahun 2008 tentang Informasi Dan Transaksi Elektronik Informasi terkait penghinaan/ pencemaran nama baik adalah lamanya pemidanaan yang berkurang dari pidana penjara paling lama 6 (enam) tahun menjadi 4 (empat) tahun sedangkan denda dari semula 1 miliar menjadi 750 juta. Adapun dampak berkurangnya ancaman pidana tersebut maka tersangka/ terdakwa tidak dapat ditahan oleh penyidik, penuntut umum maupun hakim.

Selain itu, terdapat perubahan penjelasan ketentuan Pasal 27 UndangUndang Republik Indonesia Nomor 11 Tahun 2008 tentang Informasi Dan Transaksi Elektronik Informasi yang sebelumnya tertulis "jelas" kemudian di dalam penjelasan Pasal 27 Undang-Undang Republik Indonesia Nomor 19 Tahun 2016 tentang Perubahan atas Undang-Undang Republik Indonesia Nomor 11 Tahun 2008 tentang Informasi Dan Transaksi Elektronik Informasi menjadi "Ketentuan pada ayat ini mengacu pada ketentuan pencemaran nama baik dan/atau fitnah yang diatur dalam Kitab Undang-Undang Hukum Pidana (KUHP)". Hal ini semakin memperjelas : 1). makna pencemaran nama baik dan/atau fitnah sebagaimana diatur dalam KUHP serta; 2). merubah sifat delik.

Penghinaan dalam KUHP diatur pada Bab XVI yang di dalamnya terdapat rumpun pencemaran nama baik. Secara umum penghinaan merupakan keadaan seseorang yang dituduh atas sesuatu hal yang benar faktanya namun bersifat memalukan karena diketahui oleh umum sebagaimana dimaksud Pasal 310 ayat (1) KUHP dan kebalikannya apabila yang dituduhkan itu tidak benar maka dia dianggap melakukan fitnah/ pencemaran nama baik sebagaimana maksud Pasal 311 ayat (1) KUHP. Namun jika penghinaan itu dilakukan dengan jalan lain selain "menuduh suatu perbuatan", misalnya dengan mengatakan "anjing", "asu", "sundel", "bajingan" dan sebagainya, masuk Pasal 315 KUHP dan dinamakan "penghinaan ringan" (R.Soesilo, 1995: 225)

Dalam Undang-Undang Republik Indonesia Nomor 11 Tahun 2008 tentang Informasi Dan Transaksi Elektronik Informasi penghinaan/pencemaran nama baik merupakan delik biasa sehingga dapat diproses secara hukum sekalipun tidak adanya pengaduan dari korban namun dengan mengacu pada KUHP sebagaimana maksud Undang-Undang Republik Indonesia Nomor 19 Tahun 2016 tentang Perubahan atas Undang-Undang Republik Indonesia Nomor 11 Tahun 2008 tentang Informasi Dan Transaksi Elektronik, maka delik tersebut berubah menjadi delik 
aduan (klacht delic) yang mengharuskan korban membuat pengaduan kepada pihak yang berwajib. Muatan norma penjelasan Pasal 27 Undang-Undang Republik Indonesia Nomor 19 Tahun 2016 tentang Perubahan atas Undang-Undang Nomor 11 Tahun 2008 tentang Informasi Dan Transaksi Elektronik, secara tidak langsung mengadopsi pertimbangan Putusan Mahkamah Konstitusi Nomor 50/PUU-VI/2008 Jo Putusan MK Nomor 2/PUU-VII/2009.

Dalam pertimbangan Putusan MK 50/PUU-VI/2008 disebutkan bahwa keberlakuan dan tafsir atas Pasal 27 ayat (3) Undang-Undang Republik Indonesia Nomor 19 Tahun 2016 tentang Perubahan atas Undang-Undang Nomor 11 Tahun 2008 tentang Informasi Dan Transaksi Elektronik tidak dapat dipisahkan dari norma hukum pokok dalam Pasal 310 dan pasal 311 KUHP sebagai genus delict yang mensyaratkan adanya pengaduan (klacht) untuk dapat dituntut, harus juga diperlakukan terhadap perbuatan yang dilarang dalam Pasal 27 ayat (3) UndangUndang Republik Indonesia Nomor 19 Tahun 2016 tentang Perubahan atas UndangUndang Nomor 11 Tahun 2008 tentang Informasi Dan Transaksi Elektronik, sehingga Pasal a quo juga harus ditafsirkan sebagai delik yang mensyaratkan pengaduan (klacht) untuk dapat dituntut di depan Pengadilan.

\section{KESIMPULAN}

Penghinaan/ pencemaran nama baik melalui facebook mestinya tidak terjadi kalau pengguna bijak dalam mengunggah status sehingga memberikan rasa aman bagi semua pihak. Aspek hukum penghinaan/pencemaran nama baik melalui facebook memiliki karakter yang mudah dilakukan, mudah tersebar dan diketahui publik, dapat dilakukan oleh semua pengguna, dampak langsungnya terbentuk opini publik dan lain sebagainya. Pencemaran nama baik melalui facebook bisa dijerat dengan Pasal 45 ayat (3) Undang-Undang Republik Indonesia Nomor 19 Tahun 2016 tentang Perubahan atas Undang-Undang Republik Indonesia Nomor 11 Tahun 2008 tentang Informasi Dan Transaksi Elektronik Informasi. 


\section{DAFTAR PUSTAKA}

\section{Buku}

Asshiddiqie, Jimly, Konstitusi Dan Konstitusionalisme, Sinar Grafika, Jakarta, 2010 Jumardi, Tinjauan Yuridis Terhadap Tindak Pidana Penghinaan, Unhas Makassar, 2014

Putra, Atven Vemanda, Eksistensi Pasal 27 ayat (3) Undang- Undang Nomor 11 Tahun 2008 dalam Perkara Pencemaran Nama Baik. Vol 1 No.1, Fakultas Hukum Universitas Atmajaya Yogyakarta, 2013.

R. Soesilo, Kitab Undang-undang Hukum Pidana. Politeia, Bogor, 1995.

William, RiversL Jay W. Jensen. Theodore Peterson, Media Massa dan masyarakat modern, Kencana, Jakarta, 2003.

\section{Perundang-Undangan}

Kitab Undang-Undang Hukum Pidana.

Undang-Undang Nomor 19 Tahun 2016 tentang Perubahan atas Undang-Undang Nomor 11 Tahun 2008 tentang Informasi Dan Transaksi Elektronik Informasi.

\section{Sumber Lain}

https://www.jpnn.com/news/penghina-pdip-divonis-1-tahun-penjara 